\title{
Annona muricata Extract Reduces Inflammation via Inactivation of NALP3 Inflammasome
}

\author{
Rana Mohamad Bitar ${ }^{1}$, Ragaee Ramzi Fahmi ${ }^{2}$ and Jamilah Mohamad Borjac ${ }^{{ }^{*}}$ \\ ${ }^{1}$ Faculty of Science, Beirut Arab University, P.O. Box 115020 Riad El solh 11072809; j.borjac@bau.edu.lb \\ ${ }^{2}$ Faculty of Medicine, Beirut Arab University, P.O. Box 115020 Riad El solh 11072809
}

\begin{abstract}
Annona muricata (AM) is a herb traditionally used to treat various human ailments. The mechanistic effect of Annona muricata extract on NALP3 inflammasome activation is not well understood. Objective: The present study investigates the inhibitory effects of Annona muricata extract on NALP3 inflammasome activation and its role in sepsis prevention. Methods: Sepsis was induced in mice by intraperitoneal injection of Escherichia fergusonii. Mice were treated with Annona muricata extract. Its effect on liver was assessed both histologically and biochemically. Lipid peroxidation, level of IL-1 $\beta$, TNF- $\alpha$ was measured colorimetrically and using Elisa kit in liver homogenates. The expression levels of IL-1 $\beta$, TNF- $\alpha$, caspase-1 and NALP3 genes were measured using RT-PCR. Results: AM extract significantly minimized the inflammation by decreasing the level and the expression levels of IL-1 $\beta$ and TNF- $\alpha$ in a time-dependent manner. Significant decrease in the gene expression level of caspase-1 and NALP3 was observed. Histopathologically, normal architecture of the liver of infected mice was regained after the herb treatment. Conclusion: Anonna Muricata can act as a potent therapeutic agent in treating various NALP3 associated inflammatory disorders.
\end{abstract}

Keywords: Annona muricata, Cytokines, Escherichia fergusonii, NALP3 Inflammasome

\section{Introduction}

Annona muricata L., commonly named as graviola, soursop or guanabana, belongs to the Annonaceae family ${ }^{1}$. It is cultivated throughout all tropical and subtropical regions of the world ${ }^{2}$. It is an evergreen, erect tree of large yellow flowers, shiny roundish dark green leaves and huge oval green fruit $^{3}$. Annona species, especially Annona muricata (AM), have been wellknown for their richness in Annonaceous Acetogenin compounds (AGEs) ${ }^{4}$. Phytochemical estimation of AM leaves revealed the existence of alkaloids ${ }^{5,6}$, flavonol triglycosides $^{7}$, megastigmanes ${ }^{8}$, cyclopeptides $^{9}$ and phenolic compounds ${ }^{10}$. In addition, AM leaves contain numerous minerals such as $\mathrm{K}, \mathrm{Na}, \mathrm{Ca}, \mathrm{Mg}$ and $\mathrm{Cu}$ and $\mathrm{Mg}$ that are essential for human health.

An array of human illness and disorders are traditionally cured by various parts of the AM tree. Anciently, the fruit was used to treat arthritic pain, rheumatism, dysentery, diarrhea, fever, parasites, worms and skin rushes ${ }^{11}$. The leaves are active against diabetes, cystitis, rheumatism, and headaches ${ }^{12-14}$. Seeds were used as anti-helmintic against various internal and external parasites and worms ${ }^{15}$.

The isolated AGEs from the different part of AM trees have been proven to have anti-proliferative effects against various cancer cell lines by inducing apoptosis through the mitochondrial-mediated pathway up-regulating Bax and down-regulating of $\mathrm{Bcl}-2$ gene expression and by arresting cell cycle in the G1 phase ${ }^{16,17}$. Aqueous and methanolic extracts of AM leaves revealed anti-oxidative activities against $\mathrm{H}_{2} \mathrm{O}_{2}$-induced cellular toxicity ${ }^{18}$ and antihypertensive effect through peripheral mechanisms as $\mathrm{Ca}^{2+}$ antagonist ${ }^{19}$. AM extracts also showed antinociceptive activities in vivo ${ }^{20}$ as well as anti-bacterial activities against various types of gram-positive and gram-negative bacteria including Escherichia species ${ }^{21}$. AM leaves extracts exhibited anti-inflammatory effect 
where it protected against Complete Freund's Adjuvant (CFA)-induced arthritis and xylene-induced ear edema and led to a reduction in the tumor necrosis factor alpha (TNF- $\alpha$ ) and interleukin 1 beta (IL-1 $\beta$ ) levels in rodents ${ }^{22}$.

IL- $1 \beta$, an inflammatory cytokine that is considered as an endogenous pyrogen, harbors variety of roles such as mediator of inflammatory responses, cell proliferation, differentiation and apoptosis. Synthesis and processing of IL- $1 \beta$ is under tight control. Immature IL- $1 \beta$ (pro IL-1 $\beta$ ) is stored in intracellular vesicles that are cleaved by caspase- 1 to produce the mature cytokine. IL- $1 \beta$ production is induced via innate Pathogen Recognition Receptors (PRRs) through NF- $\kappa$ B and Mitogen Activated Protein (MAP) kinase signaling pathways ${ }^{23}$. Cleavage of pro-IL- $1 \beta$ is mediated by a multi-protein complex known as 'inflammasome.' Inflammasomes are activated in response to pathogen- and danger-associated molecular patterns (PAMPs and DAMPs). They consist of a sensor protein of the NOD-like receptor family (NLR), an adaptor protein apoptosis-associated speck-like protein containing CARD (ASC) and a downstream effector caspsase-1. NALP3 is one of the best-characterized inflammasome. It serves as a scaffold for recruitment of pro-caspase- 1 and induce its auto-proteolytic activation. In turn, caspase 1 cleaves pro-IL- $1 \beta$ and pro-IL-18 into active cytokines IL- $1 \beta$ and IL-18 $8^{24-26 .}$

Cellular injuries, bacterial infections and various toxic substances induce NALP3 gene expression and complex activation ${ }^{27-29}$. NALP3 activation is through a two-signal model, a priming signal and an activation signal. The priming signal may be provided by either endogenous cytokine such as TNF- $\alpha$ or by bacterial infection leading to upregulation of NALP3 and pro-IL- $1 \beta$ through NF- $\kappa B$ signaling pathway. Different stimuli including $\mathrm{K}+$ efflux, ATP, toxins, Reactive Oxygen Species (ROS) mediate the activation of NALP 3 and production of mature IL- $1 \beta$ in the second signal ${ }^{30-32}$.

Recent studies on NALP3 inflammasome showed that it plays an essential role in Escherichia coli infection, a gram-negative enteric bacterium that can modulate innate responses ${ }^{33}$. Escherichia fergusonii is one of the Escherichia species that evolved from Escherichia coli and that is considered as a non-pathogenic bacterium.
However, recent studies showed that it induces immunological responses both in animals and in humans and it is resistant to a broad spectrum of antibiotics ${ }^{34}$.

Although the anti-inflammatory effects of AM leaves extracts have been widely reported, their effect on NALP3 inflammasome activation is not well documented. In this study we investigate the effects of AM aqueous extract on NALP3 activation and IL- $1 ß$ regulation in Balb/c mice infected with Escherichia fergusonii.

\section{Materials and Methods}

\subsection{Reagents}

Agarose was purchased from Peqlab (USA), chloroform from Fluka (USA), acetylsalicylic acid (aspirin), ethanol, bovine serum albumin, ortho-phosphoric acid, sodium chloride, potassium chloride, Thiobarbituric Acid (TBA), Trichloroacetic Acid (TCA), potassium phosphate monobasic/basic and formaldehyde were purchased from Sigma-Aldrich (USA). Coomassie brilliant blue G250 was purchased from Fisher Scientific (USA). PMSF was purchased from Roche Diagnostics (Swittzerland). $\mathrm{NaCl}$ was purchased from Serum Products. TNFa and IL-1 $\beta$ ELISA kit (cat no. ab100747 and ab100705 for IL$1 \beta$ respectively) were from Abcam (Cambridge, UK). RNeasy Mini Kit, Quantitect Reverse Transcription Kit, QuantiFast SYBR Green RT-PCR Kitwere purchased from Qiagen (Cambridge, UK).

\subsection{Preparation of the Water Extract of A. Muricata Leaves}

Sterilized and shade air-dried Annona muricata leaves were purchased from USA from Nallife Company. The leaves were of Thailand origin. Sixty grams of powdered AM leaves were soaked in $200 \mathrm{ml}$ of boiling distilled water for $30 \mathrm{~min}$. Filtrate were extracted a second time with an additional $200 \mathrm{ml}$ of boiling distilled water for $30 \mathrm{~min}$. The combined filtrates were then freeze-dried yielding a $2.43 \mathrm{~g}$ of brown, sticky precipitate that was stored at $4^{\circ} \mathrm{C}$. Aliquot of extract residues were weighed and suspended in deionized distilled water before use. 


\subsection{Animals}

Healthy female Balb/c albino mice (25-30 g) used in this study was obtained from the animal house at Beirut Arab University. The animals were housed under standard laboratory conditions (humidity $55 \pm 5 \%$, temperature $22 \pm 2{ }^{\circ} \mathrm{C}, 12 / 12 \mathrm{~h} \mathrm{light/dark}$ cycle) and had access to food and water ad libitum throughout the study. Mice were randomly divided into six experimental groups of 6 mice each. The control group received only distilled water. The aspirin group received $100 \mathrm{mg} / \mathrm{kg}$ of aspirin. The AM group received $100 \mathrm{mg} / \mathrm{kg}$ of AM extract. The E. fergusoni group were intra-peritoneally injected with $1.5 \times 10^{8}$ CFU bacterium. The E. fergusoni + aspirin group were pretreated with aspririn at $100 \mathrm{mg} / \mathrm{kg} 2$ hours prior to intraperitoneal injection with $1.5 \times 10^{8} \mathrm{CFU}$ of E. fergusoni. The E. fergusoni + AM group received 100 $\mathrm{mg} / \mathrm{kg}$ of AM extract 2 hours prior to intraperitoneal injection with $1.5 \times 10^{8} \mathrm{CFU}$ of E. fergusoni. The animals were sacrificed 6, 24 and 72 hours after treatment, their livers were used for molecular analysis and histological studies.

Ethical Consideration: All experimental procedures performed on mice were approved by the Institutional Review Board (IRB) Committee at Beirut Arab University. The animals were taken care of in accordance with the recommendations provided in the "Guide for the Care and Use of Laboratory Animals" prepared by the National Academy of Sciences.

\subsection{Induction of Peritonitis}

Peritonitis was induced by injecting $1.5 \times 10^{8} \mathrm{CFU}$ of Escherichia fergusonii ATCC35469 that was a generous gift from Al-Hayat Hospital. The bacterium was identified by $16 \mathrm{SrRNA}$ sequencing. Bacteria were cultured in Luria Bertani (LB) broth at $37^{\circ} \mathrm{C}$. They were harvested at the mid-log phase and washed twice with sterile saline before injection.

\subsection{Paraffin Tissue Processing and Hematoxylin and Eosin Staining}

Pieces of the isolated livers were washed with PBS, fixed using $10 \%$ formaldehyde for 18 hours, dehydrated through series of graded alcohol, cleared in xylene and embedded in molten paraffin wax. Tissue blocks were sectioned (4 $\mu \mathrm{m}$ thickness) using microtome (14274 microtome HM340E), deparaffinized and stained with Hematoxylin and Eosin. The sections were examined with a Zeiss Primo light microscope with axio Vision software (400x magnification) and photomicrographed using AxioCam camera for analysis.

\subsection{Tissue Homogenization}

Liver tissues were homogenized in sterilized PBS buffer $\left(137 \mathrm{mM} \mathrm{NaCl}, 2.7 \mathrm{mM} \mathrm{KCl}, 10 \mathrm{mM} \mathrm{Na} 2 \mathrm{HPO}_{4}, 2 \mathrm{mM}\right.$ $\mathrm{KH}_{2} \mathrm{PO}_{4}$, $\mathrm{pH} 7.4$ containing $1 \mathrm{mM}$ protease inhibitor PMSF). The homogenate was then centrifuged for 20 minutes at $12000 \mathrm{~g}$ at $4^{\circ} \mathrm{C}$. The supernatant was stored at $-80^{\circ} \mathrm{C}$ for later use.

\subsection{Determination of Malondialdehyde Concentration}

Lipid peroxidation was established by measuring Malondialdehyde (MDA) in the liver homogenates using thiobarbituric acid. The preparation is based on the method described previously ${ }^{35}$. In brief, thiobarbituric acid react with MDA at low $\mathrm{pH}$ and high temperature resulting in a pink adduct that absorbs at $532 \mathrm{~nm}$.

\subsection{Measurement of Inflammatory Cytokines}

The levels of IL- $1 \beta$ and TNF- $\alpha$ were measured using the Mouse ELISA Kit for IL- $1 \beta$ and TNF- $\alpha$ according to the manufacturers' protocol. In brief, immobilized antibody against the cytokine measured is bound to a 96 well plate. Samples and standards $(100 \mu \mathrm{l})$ are added to each well. After incubation followed by washing (3x, $300 \mu \mathrm{l}$ washing solution), biotinylated anti-mouse IL$1 \beta$ or TNF- $\alpha$ beta antibody is added. HRP conjugated streptavidin is next added to wells after washing unbound biotinylated antibody. TMB substrate solution is next added. The yellow color developed after adding the stop solution was measured at $450 \mathrm{~nm}$ and is proportional to the amount of bound cytokine.

\subsection{Quantitative Real-time Polymerase Chain reaction (qRT-PCR) Analysis of Gene Expression}

Total RNA were isolated from theliver homogenates using the RNeasy Plus Mini Kit according to manufacturer's recommendations. RNA concentration was determined 
by measuring the absorbance at $260 \mathrm{~nm}$ using a spectrophotometer. RNA was reverse transcribed using the QuantiTect Reverse Transcription Kit according to manufacturer's recommendations. Quantitative realtime PCR were carried out using QuantiFast SYBR Green PCR Master Mix in triplicates and was performed using the QiagenRotor-Gene Q. The thermal cycling conditions were optimized as follow: 10 seconds at $95^{\circ} \mathrm{C}$ followed by 45 cycles of amplification ( 5 seconds at $95^{\circ} \mathrm{C}$ and 30 seconds at $57^{\circ} \mathrm{C}$ ). The relative expression of each gene was calculated using the comparative threshold cycle method normalized to GAPDH gene.

The sequences of the primers used are as the following: GAPDH (forward:5'TGGTGCTCAGTGTAGCCCAG-3' and reverse:5'GGACCTGACCTGCCGTCTAG-3'); TNF- $\alpha$ forward: 5'-GAAGTTCCCAAATGGCCTCC-3', and reverse:5'TCTATGGCCCAGACCCTCAC-3'); IL-1 $\beta$ (forward: 5'-TGGGCCTCAAAGGAAAGA-3', and reverse: 5'-GGTGCTGATGTACCAGTT-3'); NALP3 (forward: 5'ATTACCCGCCCCGAGAAAGG-3, and reverse: 5'-CTGTGTGGATCTTTGCTGCGA-3');Caspase-1 (forward: 5'-CGTGGAGAGAAACAAGGAGTG-3 and reverse: 5'-AATGAAAAGTGAGCCCCTGAC-3').

Relative gene expression was calculated using the $2^{-\triangle \Delta C T}$ Gene Dosage Ratio formula (GDR) where the difference between mean Cycle threshold $(\mathrm{Ct})$ of gene of interest and mean cycle threshold of GAPDH gene in control samples are subtracted from their differences in test sample according to the following equation.

$\Delta \Delta \mathrm{Ct}=(\mathrm{mCt}$ gene of interest $-\mathrm{mCt} \mathrm{GAPDH})$ test sample - (mCt gene of interest - mCt GAPDH) control sample.

\subsection{Statistical Analysis}

All statistical analyses were performed using Graph Pad Prism Ver 7 . The data are expressed as mean \pm standard deviation $(n=3)$. In all tests, the minimum criterion for the statistical significance was $p<0.05$. Statistical analysis of the obtained results was analyzed using Oneway ANOVA. P-values of less than 0.05 were considered significant.

\section{Results}

\subsection{Effect of AM Extract on Liver}

Histopathology of the livers of normal control mice showed typical hepatolobular architecture, consisting of a central vein with radiating cords of hepatocytes separated by sinusoids. The hepatocytes are polygonal in shape, with central, lightly stained nuclei and prominent nucleolus. The cytoplasm is regularly distributed (Figure 1a).

However, the livers of mice treated with aspirin or AM extract showed deranged architecture of the hepatocyte with mild cloudy swelling and vascular congestion (Figure 1).

On the other hand, liver of mice injected with E. fergusonii showed moderate vascular congestion with slight leukocyte infiltration after 6 hours (Figure 2a). However, after 24 hours, deranged sinusoidal arrangement with dilatation, multiple bi-nucleated cells with undistinguished nucleoli, low to moderate vascular congestion, and hydropic degeneration were observed (Figure 2b). Non-occluding thrombosis and fibrin accumulation were seen after 72 hours (Figure 2c).

Liver of mice treated with aspirin prior to bacterial infection and sacrificed after 6 hours showed mild hepatosteatosis (Figure 3a). Those sacrificed after 24 and 72 hours showed lower leukocytes infiltration and vascular congestion with diminutive hydropic degeneration (Figures $3 b$ and $3 c$ ).

On the other hand, treating infected mice with AM extract showed great anti-inflammatory effects. It reduced the vascular congestion, the leukocyte infiltration and the hydropic degeneration after 6 hours (Figure 3d). Liver of mice sacrificed after 24 and 72 hours appeared almost normal (Figure $3 e$ and $3 f$ ).

\subsection{Effect of AM Extract on MDA Levels}

MDA levels were determined in the liver homogenates of all groups after 6, 24 and 72 hours. As shown in Figure 4, both aspirin and AM extract had no significant effect on MDA levels compared to normal 


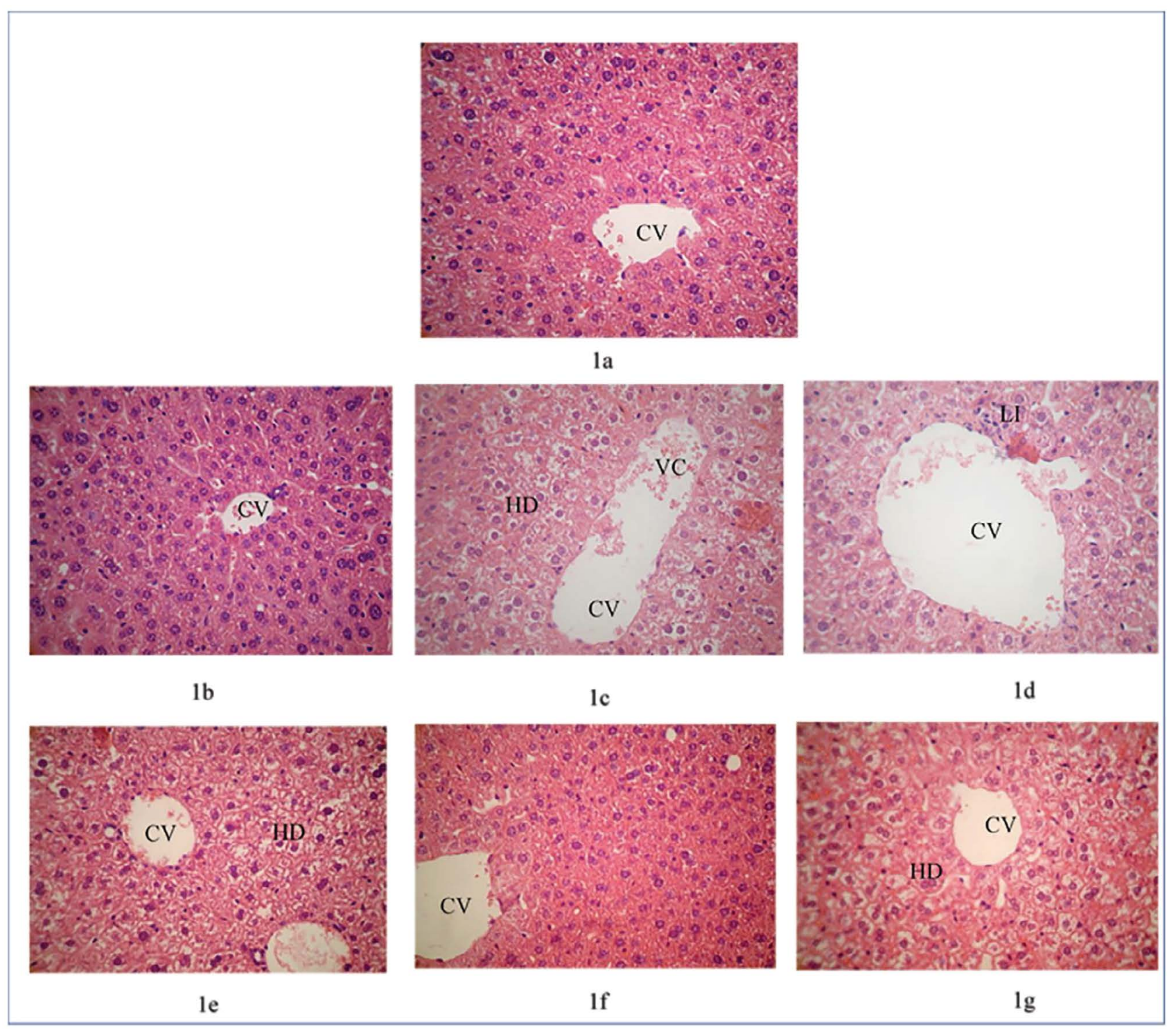

Figure 1. Liver sections from control groups. Figure 1a shows normal architecture of the liver with the central vein (CV) (1a). Figures $1 \mathrm{~b}, 1 \mathrm{c}$ and $1 \mathrm{~d}$ show sections of liver from mice that received aspirin ( $100 \mathrm{mg} / \mathrm{kg}$ ), and sacrificed after 6,24 and 72 hours. After 6 hours, a deranged sinusoidal arrangement with dilatation and slight vascular congestion is observed (1b). Mild Hydropic Degeneration (HD) and Vascular Congestion (VC) were observed after 24 hours (1c). After 72 hours, Leukocytes Infiltration (LI) was seen in addition to the mild HD and VC (1d). Figures 1e, $1 \mathrm{f}$ and $1 \mathrm{~g}$ show sections of liver from mice that were pre-treated with $100 \mathrm{mg} / \mathrm{kg} \mathrm{AM}$ extract and sacrificed after 6, 24 and 72 hours. Moderate HD was observed after 6 hours (1e) and slight fat deposition were seen after 24 hours (1f). HD persisted after 72 hours (1g) (H and E x400).

control. However, the MDA level in liver of mice infected with E. fergusonii exhibited an increase in MDA levels implying significant ROS generation. A significant decreased in MDA level was observed in mice that were pretreated with aspirin or AM extract two hours prior to bacterial injection (Figure $4 \mathrm{a}$ and $4 \mathrm{~b})$. Hence, AM extract protected the liver from ROS production and alleviating the hepatic necrosis seen in untreated infected mice (Figure 4).

\subsection{Effect of AM Extract on TNF- $\alpha$ and IL-1 $\beta$ Production in Balb/c mice}

Aspirin had no significant effect on TNF- $\alpha$ release. The level of TNF- $\alpha$ increased in liver of mice treated with AM Extract alone within 24 hours, then returned to normal. 


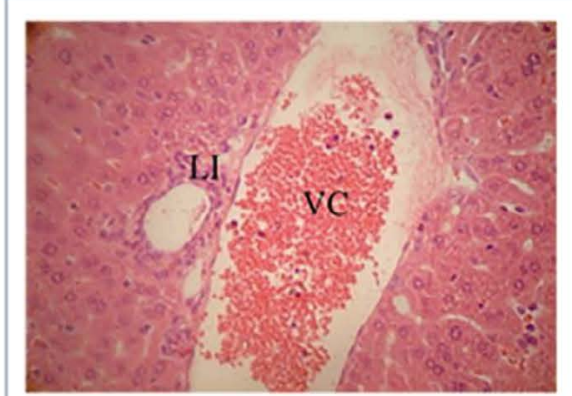

2a

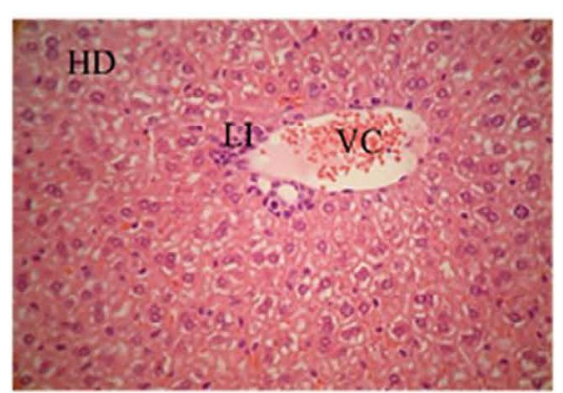

$2 \mathrm{~b}$

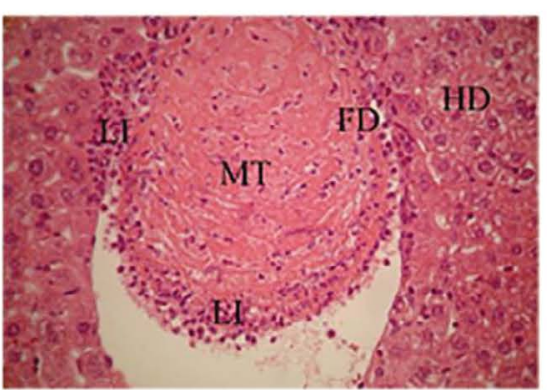

$2 \mathrm{c}$

Figure 2. Sections of liver from mice intra-peritoneally injected with $1.5 \times 10^{8}$ E. fergusonii and sacrificed after 6, 24 and 72 hours. Severe Vascular Congestion (VC) and Leukocytes Infiltration (LI) were observed after 6 hours (2a). After 24 hours, mild hydropic degeneration, vascular congestion, and leukocytes infiltration were observed (2b). Macroscopic non-occluding thrombus (MT) with massive lymphocytes infiltration surrounding the thrombus, Fibrin Deposit (FD) and Hydropic Degeneration (HD) were seen after 72 hours (2c) (H and E x400).

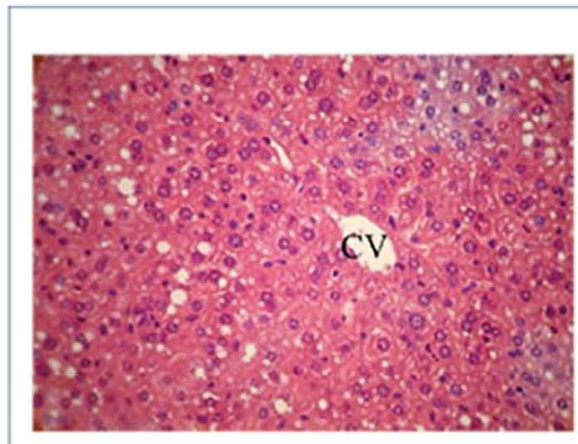

3a

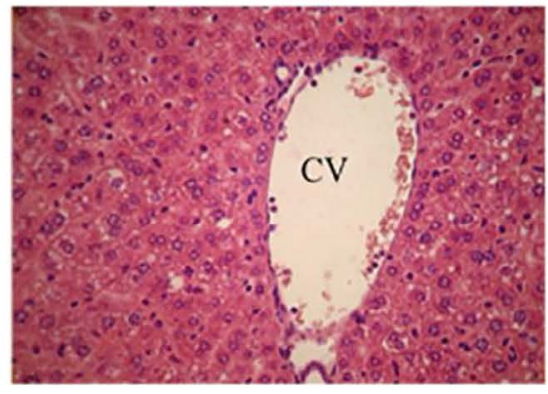

$3 \mathrm{~d}$

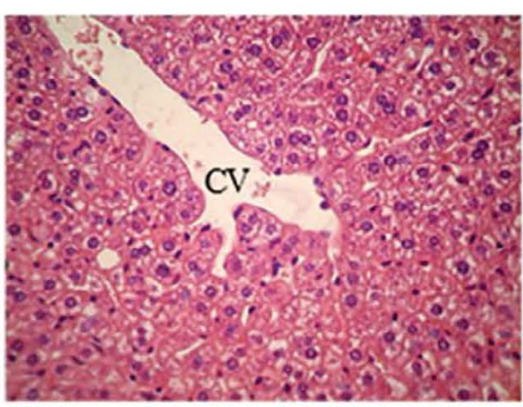

$3 b$

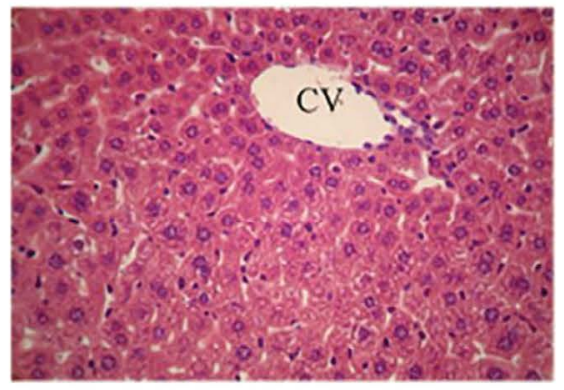

$3 \mathrm{e}$

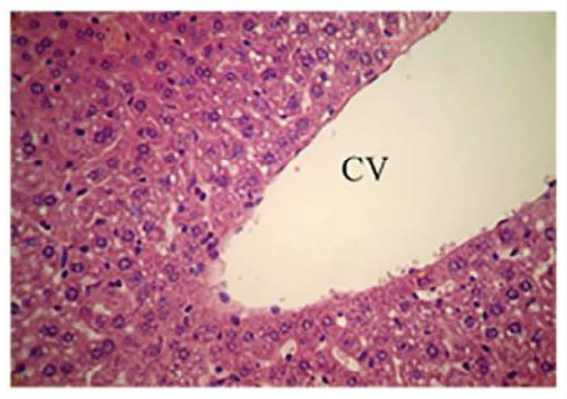

$3 \mathrm{c}$

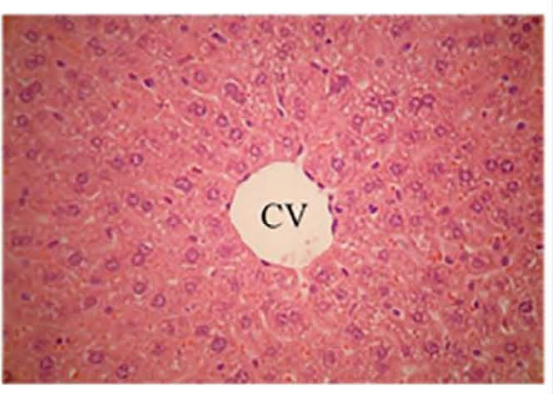

$3 \mathrm{f}$

Figure 3. Sections of liver from mice pre-treated with $100 \mathrm{mg} / \mathrm{kg}$ aspirin 2 hours prior to $E$. fergusonii infection and sacrificed after 6 hours (3a), 24 hours (3b) and 72 hours (3c). After 6 hours, mild hepatosteatosis consisting of mixed macrovascular and microvascular fat accumulation were observed (3a). After 24 hours, mild cloudy swelling, vascular congestion and mild inflammation were seen (3b). After 72 hours, significant decrease in the hydropic degeneration and inflammation was observed (3c). Figures $3 \mathrm{~d}, 3 \mathrm{e}$ and $3 \mathrm{f}$ show sections of liver from mice that received $100 \mathrm{mg} / \mathrm{kg}$ AM extract, 2 hours prior to bacterial infection and sacrificed after 6, 24 and 72 hours respectively. After 6 hours, mild vascular congestion and mild inflammation were observed (3d). Significant improvement of the cellular degeneration and better sinusoidal arrangement were seen after 24 hours (3e). Liver architecture returned back to normal after 72 hours (3f) ( $\mathrm{H}$ and E x400). 


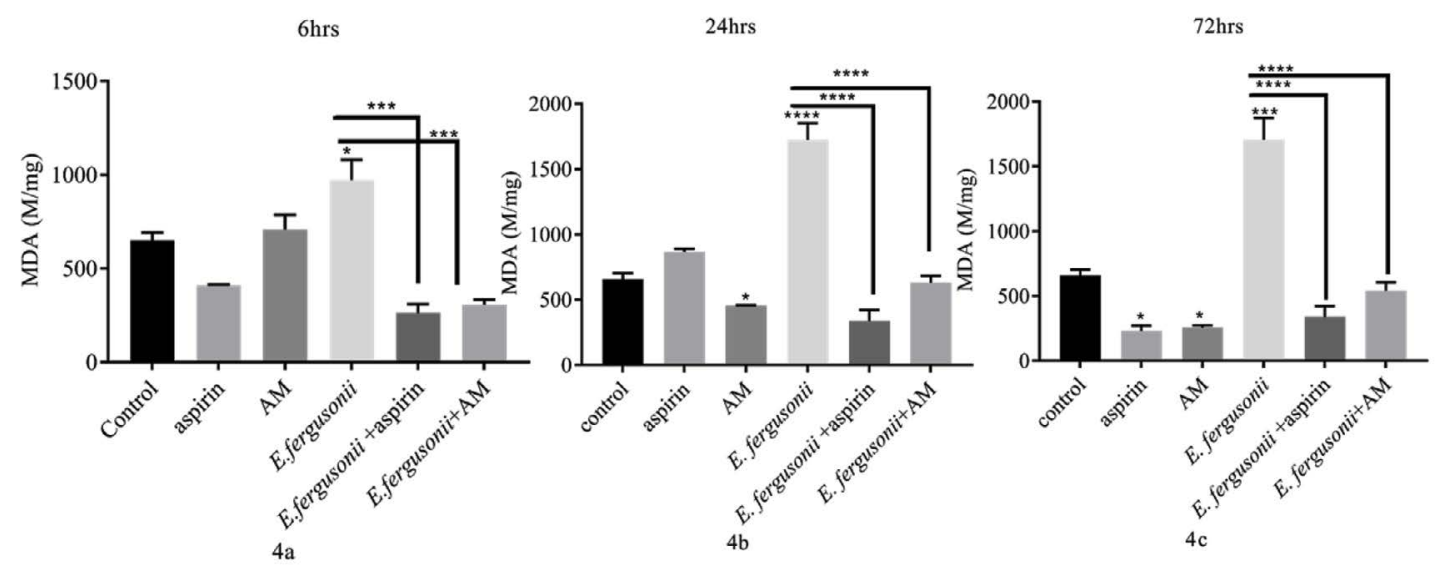

Figure 4. The effect of AM extract on MDA levels in liver homogenates of Balb/c mice. The levels of MDA were measured after 6 hours (4a), 24 hours (4b) and 72 hours (4c). Data are expressed as mean $\pm S D(n=3)$. Statistical analysis was performed using One-way ANOVA. ${ }^{*} p<0.05,{ }^{* *}<0.01$, and ${ }^{* * *}<0.001$.

However, the level of TNF- $\alpha$ significantly increased in mice infected with E. fergusonii compared to normal mice in a time dependent manner. The levels returned to normal upon treatment with aspirin or AM extract after 6 hours (Figure 5a, 5b, 5c).

As for IL-1 $\beta$ level, aspirin had no significant effect on IL-1 $\beta$ production. Interestingly, AM extract induced a significant increase in IL-1 $\beta$ level after 6 hours then returned to less than normal after 72 hours. Bacterial infection induced a significant release of IL- $1 \beta$ after 6 and 72 hours post infection. Treating infected mice with aspirin or AM extract led to a significant decrease in IL- $1 \beta$ production (Figure $5 \mathrm{~d}, 5 \mathrm{e}$ and $5 \mathrm{f}$ ). Therefore, AM extract minimized hepatic necrosis induced by E. fergusonii infection through the decreasing level of the innate immune cytokines IL- $1 \beta$ and TNF- $\alpha$.

\subsection{AM Extract Down-Regulates Inflammasome-related Gene Expression in Infected Balb/c Mice}

The effect of AM extract on the expression of TNF- $\alpha$ that activate the priming signal of NALP3 and on the expression of downstream signaling genes in the NALP3mediated response to E. fergusonii (IL-1 $\beta$, caspase- 1 and NALP3) was studied. Aspirin alone had no significant effect on TNF- $\alpha$ expression. AM extract significantly up regulated the expression level of TNF- $\alpha$ and caspase-1 after 24 hours. These results corroborate with the

up-regulation of IL-1 $\beta$ production and consistent with the hepatic necrosis observed after 6 hours (Figures 5 and 6). As expected, E. fergusonii infection up-regulated the expression levels of TNF- $\alpha$, IL- $1 \beta$, caspase- 1 and NALP3. Treatment of these mice with both aspirin and AM extract led to the down-regulation in the expression levels of these genes. These results showed that AM extract greatly reduces NALP3 inflammasome pathway that was activated in response to E. fergusonii infection.

\section{Discussion}

NALP3 inflammasome is well known for its involvement in various diseases including bacterial inflammation. It induces the overproduction of different cytokines involved in the innate inflammatory response ${ }^{36}$. Gramnegative bacterial infection leads to the release of IL-1 $\beta$ through caspase-1 activation, a downstream effector of NALP3 signaling. Overproduction of IL- $1 \beta$ leads to chronic inflammation and sepsis. Much attention is given nowadays to natural therapies that can act as specific NALP3 inhibitors ${ }^{25}$. Annona muricata possesses anti-inflammatory and anti-bacterial effects. Its involvement in NALP3 signaling is not well established yet. This study investigated the effect of AM extract on NALP3 inflammasome in E. fergusonii-induced septic peritonitis model. 

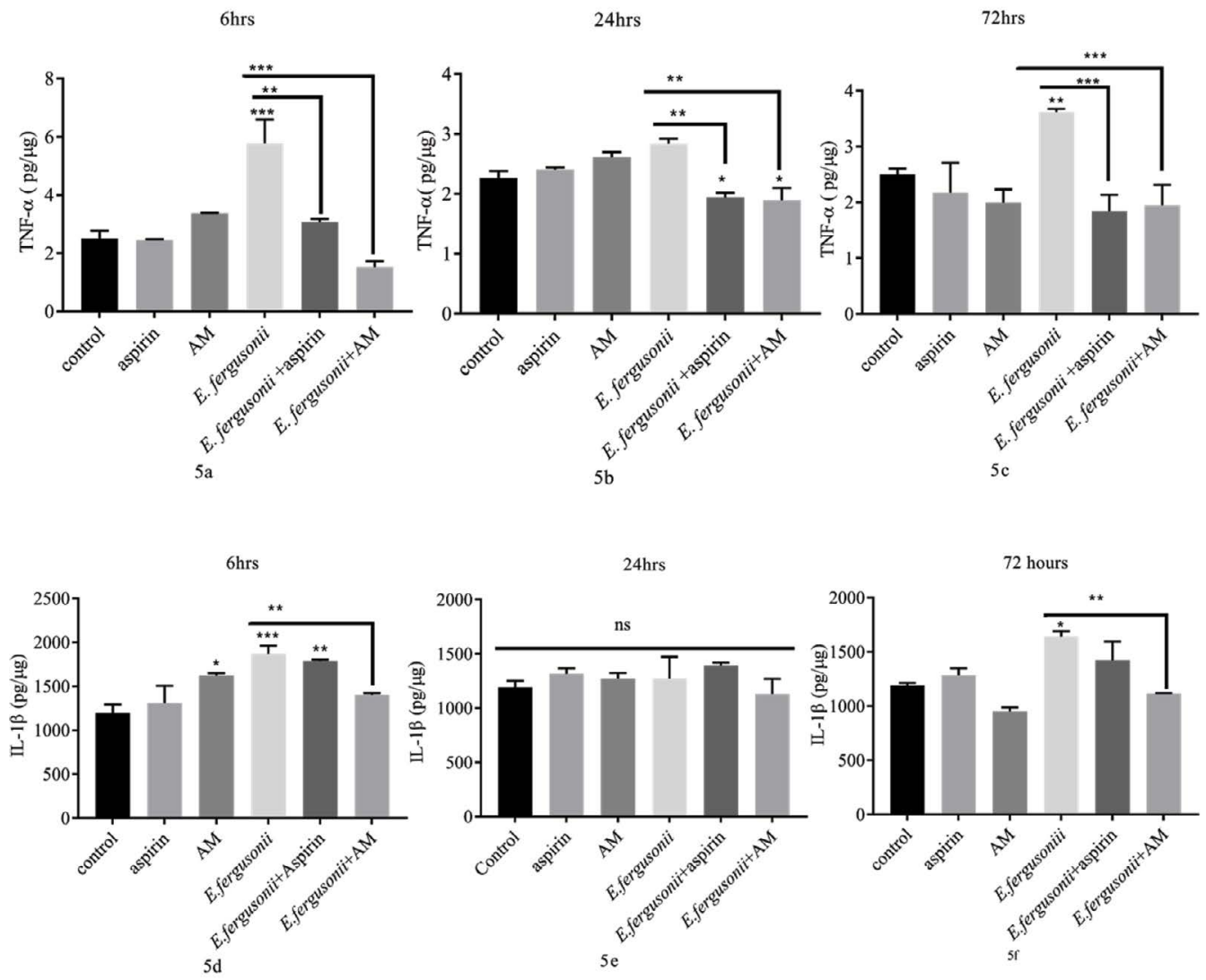

Figure 5. The effect of AM extract on TNF- $\alpha$ and IL-1 $\beta$ levels in liver homogenate of Balb/c mice. TNF- $\alpha$ and IL-1 $\beta$ levels were measured in the liver homogenates of mice sacrificed after 6 hours (4a, 4d), 24 hours (4b, 4e) and 72 hours $(4 c, 4 f)$ after treatment. Data are expressed as mean $\pm S D(n=3)$. Statistical analysis was performed using One-way ANOVA ${ }^{*} \mathrm{p}<0.05,{ }^{* *}<0.01$, and ${ }^{* * *}<0.001$.

E. fergusonii induced symptoms of sepsis was confirmed macroscopically, microscopically and biochemically. Shivering, crouched position and ruffled fur were main characteristics seen in septic mice. A mortality rate of $44 \%$ was obtained in infected untreated mice 24 hours post-infection (data not shown). Signs of infection were observed 6 hours post-infection and subsided after 24 hours if the mouse survived. The signs completely disappeared after 72 hours. The disappearance of septic features could be due to activation of innate immune responses. Aspirin treatment led to $23 \%$ a decrease in mortality rate. On the other hand, pretreatment with AM extract minimized all features of sepsis with $0 \%$ mortality rate. Therefore, AM extract possesses strong antibacterial effect.

Macroscopically, livers of mice infected with E. fergusonii displayed global necrosis with white patches throughout. None were observed in control mice given either aspirin or AM extract. Treating infected mice with aspirin led to a reduction in the observed necrosis. However, pre-treatment with AM extract completely protected the liver from the damage induced by E. fergusonii (data not shown). Furthermore, the histological examination confirmed our macroscopic examinations. AM extract significantly lessened the global hepatic necrosis seen in infected untreated mice in a time dependent manner. It prevented thrombosis after 72 hours. This prevention was not observed with aspirin treatment. Thrombosis formation is due to the role of neutrophils that are the central components of innate immune system ${ }^{37}$. They prevent bacterial dissemination by Neutrophil Extracellular Traps (NET) that promotes the formation of immune thrombosis. Thrombosis traps the circulating bacteria, avoid tissue attack and lessen the surviving bacteria in spleen and liver ${ }^{38}$. AM extract was able to inhibit the formation of immune thrombosis 

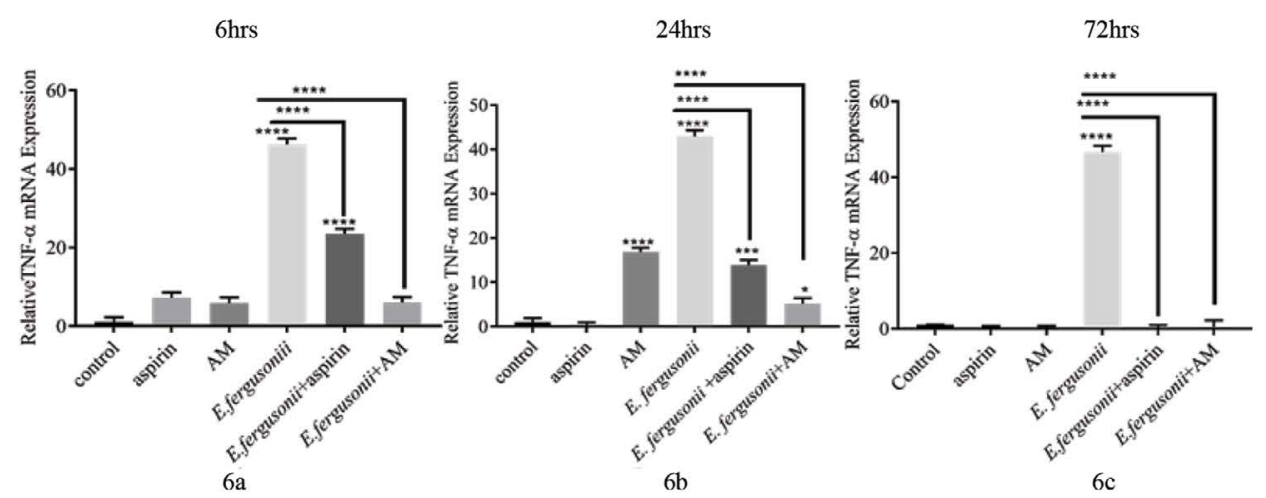

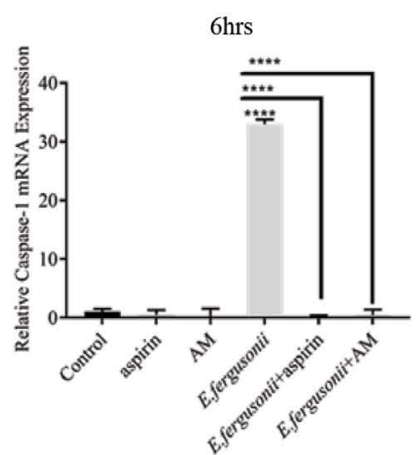

$6 \mathrm{~d}$

$6 \mathrm{hrs}$

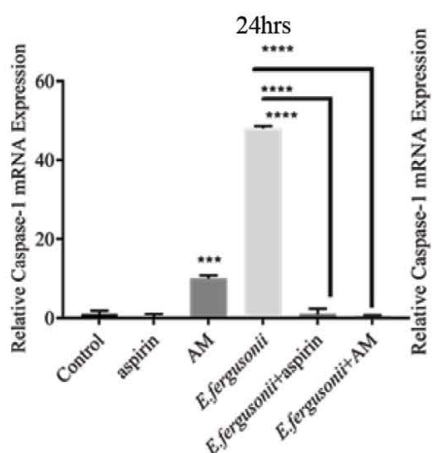

$6 \mathrm{e}$

24hrs

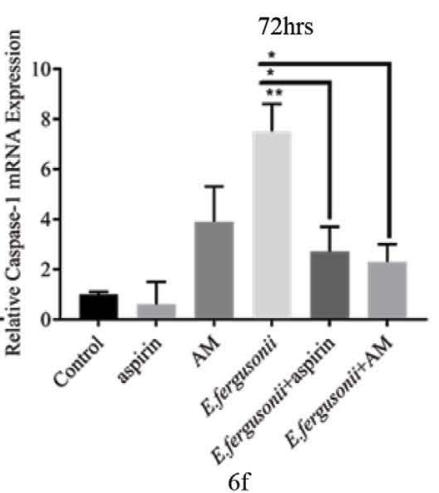

$72 \mathrm{hrs}$

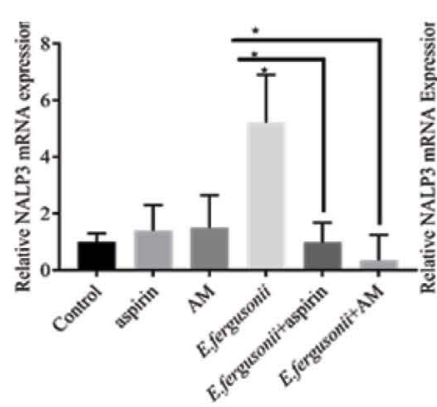

$6 \mathrm{~g}$

$6 \mathrm{hrs}$

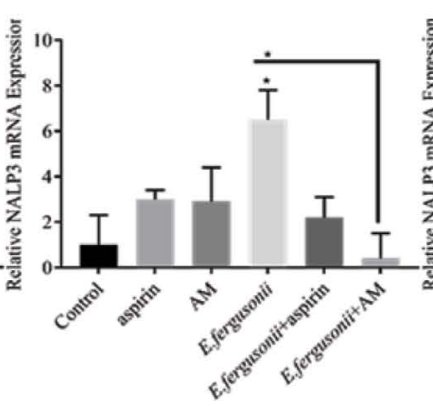

$6 \mathrm{~h}$ 24hrs

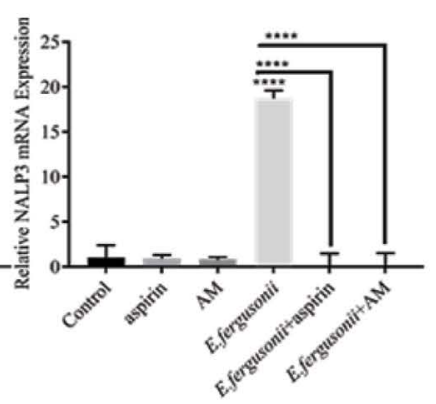

$6 \mathrm{i}$ $72 \mathrm{hrs}$

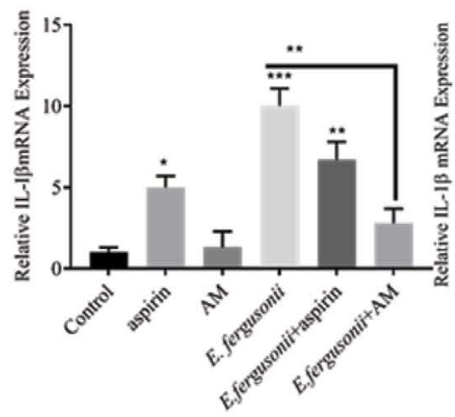

$6 \mathrm{j}$

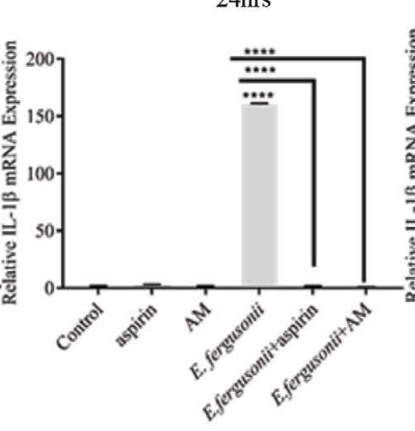

$6 \mathrm{k}$

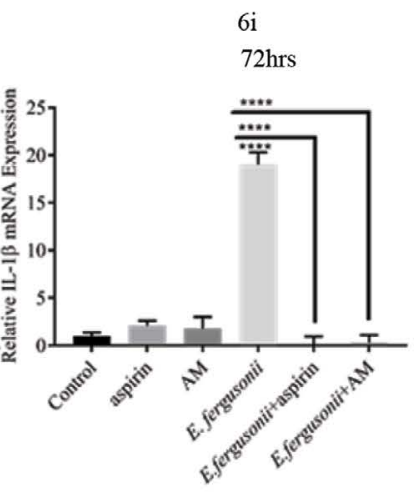

61

Figure 6. Effect of AM extract on the expression of TNFa, IL-1 $\beta, N A L P 3$, and caspase-1 genes in liver of Balb/c mice. Expression levels of treated and controls were normalized to their respective GAPDH. Fold expression was determined relative to the control. All bars represent mean of three determinations \pm SEM. $\left({ }^{*}\right),\left(^{* *}\right),\left({ }^{* * *}\right),\left({ }^{* * *}\right)$ correspond to $\mathrm{p}$ value $<0.05,0.01,0.001$, and 0.0001 respectively. Asterisks drawn upwards represent inter-categorical statistical significance 
induced by E. fergusonii and eliminated its existence in the liver. Moreover, AM extract reduced the vascular congestion and leukocytes infiltration observed in untreated infected mice 6 hours post infection, leading to normal hepatic architecture after 24 hours. This confirms the antibacterial effect that AM extract possesses.

Biochemically, AM extract eliminated hepatic necrosis by minimizing the levels of reactive oxygen species that induce membrane damage. MDA is the products of lipid peroxidation and the major indicator of ROS-dependent tissue damage in numerous organs including liver ${ }^{39,40}$. AM extract caused a significant decrease in MDA levels in infected mice confirming its anti-oxidative protective role. The hepato-protective effect of AM extract was reported in several studies and it protects DNA against $\mathrm{H}_{2} \mathrm{O}_{2}$-induced toxicity ${ }^{41}$. AM is rich in anti-oxidant (vitamin $\mathrm{E}$ and $\mathrm{C}$ ), contains high superoxide dismutase, catalase activity ${ }^{42}$ and elevated GSH levels ${ }^{43}$. All these enzymatic and non-enzymatic anti-oxidants lowers MDA levels. ROS secretion was essential for NALP3 activation ${ }^{44}$ and ROS inhibitors reduce the activity of NALP3 at the activation signal ${ }^{45}$.

The levels of the inflammatory markers IL-1 $\beta$ and TNF- $\alpha$ levels were significantly high 6 hours postinfection in untreated infected mice. They decreased within 24 hours then rose again at 72 hours. These results are attributed to the innate physiological response. In this study, we proved that AM extract down-regulated the innate inflammatory cytokines TNF- $\alpha$ and IL- $1 \beta$ in the E. fergusonii infected hepatic tissues in a time dependent manner. The level of these biochemical parameters is consistent with the histopathological results (Figure 2 versus Figure 5). Therefore, hepatic protection is conferred through reduction of the inflammatory cytokines expression.

During bacterial infection, activated Kupffer cells secrete the inflammatory mediator TNF- $\alpha$ that primes $N F-\kappa B$ and activates caspase- 1 to secrete IL- $1 \beta^{30}$. AM extract down-regulated TNF- $\alpha$ leading to the inhibition of IL- $1 \beta$ production at the priming and activation stages of NALP3 pathway. The levels of NALP3, TNF- $\alpha$, caspase- 1 , and IL- $1 \beta$ gene expression were assessed in this study. IL- $1 \beta$ significantly increased at 6,24 and 72 hours post-bacterial infection.
AM administration to normal mice also led to a significant increase in the level of IL-1 $\beta$ at 6 hours and then decreased afterwards. An increase in gene expression level of caspase-1 and TNF- $\alpha$ was also observed at 24 hours and then decreased. Metabolism of the AM active ingredients in the liver could have induced the increase in IL-1 $\beta$ at 6 hours (Figure 5) which in turn led to the activation of gene expression of caspase-1 and TNF-a (Figure 6). These changes are consistent with the slight hepatic changes observed with AM extract treatment at 6 hours.

\section{Conclusions}

AM extract was able to prevent the release of IL-1 $\beta$ via inhibition of NALP3 activation at the priming and activation signals. It was able to attenuate oxidative stress as shown by lower MDA levels. AM extract downregulated NALP3 activity making this herb an efficient antibacterial and anti-inflammatory agent. Our results offer a novel inflammasome-associated mechanism for Anonna muricata that can be considered as therapeutic agent in treating NALP3 associated inflammatory disorders.

\section{Acknowledgement}

Special thanks to Dr. Leila Akil for preparation of histological slides.

\section{References}

1. Moghadamtousi SZ, Fadaeinasab M, Nikzad S, Mohan G, Ali HM, Kadir HA. Annona muricata (Annonaceae): a review of its traditional uses, isolated acetogenins and biological activities. Int J Mol Sci. 2015; 16(7):15625-58. https://doi.org/10.3390/ijms160715625

2. Adewole SO, Caxton-Martins EA. Morphological changes and hypoglycemic effects of Annona muricata Linn. (Annonaceae) leaf aqueous extract on pancreatic B-cells of streptozotocin-treated diabetic rats. Afr J Biomed Res. 2006; 9:173-87. https://doi.org/10.4314/ajbr.v9i3.48903

3. De Souza R, Benassi E, da Silva RR, Afonso S, Scarminio IS. Enhanced extraction yields and mobile phase separations by solvent mixtures for the analysis of metabolites in Annona muricata L. Leaves. J Sep Sci. 2009; 32:4176-85. https://doi.org/10.1002/jssc.200900375 
4. Jimenez VM, Gruschwitz M, Schweiggert RM, Carle R, Esquivel P. Identification of phenolic compounds in soursop (Annona muricata) pulp by high-performance liquid chromatography with diode array and electrospray ionization mass spectrometric detection. Food Res Int. 2014; 65:42-6. https://doi.org/10.1016/j.foodres.2014.05.051

5. Mishra S, Ahmad S, Kumar N, Sharma BK. Annona muricata (the cancer killer): A review. Glob J Pharm Res. 2013; 2:1613-8.

6. Ong H, Norzalina J. Malay herbal medicine in Gemencheh, Negri Sembilan, Malaysia. Fitoterapia. 1999; 70:10-4. https://doi.org/10.1016/S0367-326X(98)00023-9

7. Wu FE, Gu ZM, Zeng L, Zhao GX, Zhang Y, McLaughlin $\mathrm{JL}$, et al. Two new cytotoxic mono-tetrahydrofuran annonaceous acetogenins, annomuricins $\mathrm{a}$ and $\mathrm{b}$ from the leaves of Annona muricata. J Nat Prod. 1995; 58:830-6. https://doi.org/10.1021/np50120a002

8. Matsushige A, Matsunami K, Kotake Y, Otsuka H, Ohta S. Three new megastigmanes from the leaves of Annona muricata. J Nat Med. 2012; 66:284-91. https://doi.org/10.1007/ s11418-011-0583-1

9. Pelissier Y, Marion C, Kone D, Lamaty G, Menut C, Bessiere J.-M. Volatile components of Annona muricata L. J. Essent. Oil Res. 1994; 6:411-4. https://doi.org/10.1080/10412905.19 94.9698410

10. Yang C, Gundala SR, Mukkavilli R, Vangala S, Reid MD, Aneja R. Synergistic interactions among flavonoids and acetogenins in graviola (Annona muricata) leaves confer protection against prostate cancer. Carcinogenesis. 2015; 36(6):656-65. doi:10.1093/carcin/bgv1046

11. Morton JF. Caribbean and Latin american folk medicine and its influence in the United States. Q J Crude Drug Res. 1980; 18(2):57-75. https://doi.org/10.3109/13880208009065179

12. Gajalakshmi S, Vijayalakshmi S, Rajeshwari Devi V. Phytochemical and pharmacological properties of Annona muricata: A review. Int J Pharm Sci. 2012; 4(2):3-6.

13. Leboeuf M, Cave A, Bhaumik P, Mukherjee B, Mukherjee R. The phytochemistry of the Annonaceae. Phytochemistry. 1980; 21:2783-813. https://doi.org/10.1016/0031-9422(80)85046-1

14. De Souza EB, Benassi E, da Silva RR, Afonso S, Scarminio IS. Enhanced extraction yields and mobile phase separations by solvent mixtures for the analysis of metabolites in Annona muricata L. Leaves. J Sep Sci. 2009; 32:4176-85. https://doi.org/10.1002/jssc.200900375

15. Taylor L. Technical data report for graviola, Annona muricata, Vol. 10 Austin: Sage Press; 2002. p. 1-6.

16. Moghadamtousi SZ, Kadir HA, Paydar M, Rouhollahi E, KarimianH.Annonamuricataleavesinducedapoptosisin A549 cells through mitochondrial-mediated pathway and involvement of NF- $\kappa$ B. BMC Complement Altern Med. 2014; 14:29. https://doi.org/10.1186/1472-6882-14-299
17. Arroyo J, Prashad M, Vasquez Y, Li E, Tomas G. Actividadcitotoxica in vitro de la mezcla de Annona muricata y krameria lappacea sobre celulas cancerosas de glandula mamaria, pulmony Sistema nervioso central (in Spanish). Rev Peru Med Exp. 2005; 22:247-53.

18. George VC, Kumar DN, Suresh P, Kumar RA. Antioxidant, DNA protective efficacy and HPLC analysis of Annona muricata (soursop) extracts. J Food Sci Technol. 2015; 52(4):2328-35. https://doi.org/10.1007/s13197-014-1289-7

19. Nwokocha CR, Owu DU, Gordon A, Thaxter K, McCalla G, Ozolua RI. Possible mechanisms of action of the hypotensive effect of Annona muricata (soursop) in normotensive sprague-dawley rats. Pharm Biol. 2012; 50:1436-41. https://doi.org/10.3109/13880209.2012.684690

20. Hamid RA, Foong CP, Ahmad Z, Hussain MK. Antinociceptive and anti-ulcerogenic activities of the ethanolic extract of Annona muricata leaf. Rev Bras Farmacogn. 2012; 22:63041. https://doi.org/10.1590/S0102-695X2012005000001

21. Viera GHF, Mourao JA, Angelo AM, Costa RA, Vieira RHSDF. Antibacterial effect (in vitro) of Moringa oleifera and Annona Nuricata against gram positive and gram negative bacteria. Rev Inst Med Trop Sao Paulo. 2010;52(3):129-32. PMid: 20602021. https://doi.org/10.1590/S0036-46652010000300003

22. Roslida A, Tay C, Zuraini A, Chan P. Anti-inflammatory and anti-nociceptive activities of the ethanolic extract of Annona muricata leaf. J Nat Rem. 2010; 10:97-104.

23. Martinon F, Mayor A, Tschopp J. The inflammasomes: Guardians of the body. Annu Rev Immunol. 2009; 27:229-65. https://doi.org/10.1146/annurev.immunol.021908.132715

24. Muruve DA, Petrilli V, Zaiss AK, White LR, Clark SA, Ross $\mathrm{PJ}$, et al. The inflammasome recognizes cytosolic microbial and host DNA and trigger innate immune response. Nature. 2008; 452:103-7. https://doi.org/10.1038/nature06664

25. Schroder K, Tschopp J. The inflammasomes. Cell. 2010; 140:821-32. https://doi.org/10.1016/j.cell.2010.01.040

26. Martinon F, Burns K, Tschopp J. The inflammasome: A molecular platform triggering activation of inflammatory caspases and processing of pro IL-beta. Mol Cell. 2002; 10:417-26. https://doi.org/10.1016/S1097-2765(02)00599-3

27. Mandrekar P, Ambade A, Lim A, Szabo G, Catalano D. An essential role for monocyte chemoattractant protein 1 in alcoholic liver injury: Regulation of proinflammatory cytokines and hepatic steatosis in mice. Hepatology. 2011; 54:2185-97. https://doi.org/10.1002/hep.24599

28. Aksentijevich I, Putnam CD, Remmers EF, Mueller JL, Le J, Kolodner RD, et al. The clinical continuum of cryopyrinopathies. Arthritis Rheum. 2007; 56:1273-85. https://doi.org/10.1002/art.22491

29. Shinkai K, McCalmont TH, Leslie KS. Cryopyrin-associated periodic syndromes and auto-inflammation. Clin Exp. Dermatol. 2008; 33(1):1-9. https://doi.org/10.1111/j.13652230.2007.02540.x 
30. Guo H, Callaway JB, Ting JB. Inflammasomes: Mechanism of action, role in disease and therapeutics. Nat Med. 2015; 21(7):677-87. https://doi.org/10.1038/nm.3893

31. Liston A, Masters SL. Homeostasis-altering molecular processes as mechanisms of inflammasome activation. Nat Rev Immunol. 2017; 17(3):208-14. https://doi.org/10.1038/ nri.2016.151

32. Alvarez S, Munoz-Fernandez MA. TNF- $\alpha$ may mediate inflammasome activation in the absence of bacterial infection in more than one way. PLoS ONE 2013; 8(8):e71477. https://doi.org/10.1371/journal.pone.0071477

33. Yen H, Karino M, Tobe T. Modulation of the inflammasome signaling pathway by enteropathogenic and enterohemorrhagic Escherichia coli. Front Cell Infect Microbiol. 2016; 26(6):89. https://doi.org/10.3389/fcimb.2016.00089

34. Forgetta V, Rempel H, Malouin F, Vallencourt R Jr, Topp E, Dewar K. Pathogenic and multidrug-resistant Escherichia fergusonii from broiler chicken. Poultry Science. 2012; 91:512-25. https://doi.org/10.3382/ ps.2011-01738

35. Janero DR. Malondialdehyde and thiobarbituric acid-reactivity as diagnostic indices of lipid peroxidation and peroxidative tissue injury. Free Radic Biol Med. 1990; 9:515-40. https://doi.org/10.1016/0891-5849(90)90131-2

36. Schroder K, Zhou R, Tschopp J. The NLRP3 inflammasome: A sensor for metabolic danger? Science. 2010; 327:296-300. https://doi.org/10.1126/science.1184003

37. Swystun LL, Liaw PC. The role of leukocytes in thrombosis. Blood. 2016; 128:753-62. https://doi.org/10.1182/blood2016-05-718114

38. Massberg S, Grahl L, von Bruehl ML, Manukyan D, Pfeiler $\mathrm{S}$, Goosman C, et al. Reciprocal coupling of coagulation and innate immunity via neutrophil serine proteases. Nat Med. 2010; 16(8):887-96. https://doi.org/10.1038/nm.2184

39. Kwiecien S, Pawlik MW, Brzozowski T, Pawlik WW, Konturek SJ. Reactive oxygen metabolite action in experimental, stress model of gastric mucosa damage. Gastroenterol Pol. 2010; 17:234-43.

40. Moldovan L, Moldovan NI. Oxygen free radicals and redox biology of organelles. Histochemistry and Cell Biology. 2004; 122(4):395-412. https://doi.org/10.1007 /s00418-004-0676-y

41. George VC, Kumar DN, Suresh P, Kumar RA. Antioxidant, DNA protective efficacy and hplc analysis of Annona muricata (soursop) extracts. J Food Sci Technol. 2015; 52:2328-35. https://doi.org/10.1007/s13197-014-1289-7

42. Vijayameena C, Subhashini G, Loganayagi M, Ramesh B. Phytochemical screening and assessment of antibacterial activity for the bioactive compounds in Annona muricata. Int. J Curr Microbiol Appl Sci. 2013; 2:1-8.

43. Mohamed ET, El-Sayed Mahdy ME, Singer GM, ElKiki1 S, Elias MS. Role of Annona muricata (L.) in oxidative stress and metabolic variations in diabetic and gammairradiated rats. Egypt. J Rad Sci Applic. 2017; 30:1-11. https://doi.org/10.21608/ejrsa.2017.1183.1012

44. Bauernfeind F, Bartok E, Rieger A, Franchi 1,Nú-ez G, HornungV. Cutting edge: Reactive oxygen species inhibitors block priming, but not activation, of the NLRP3 inflammasome. J Immunol. 2011; 187:613-7. https://doi. org/10.4049/jimmunol.1100613

45. Munoz-Planillo R, Kuffa P, Martinez-Colon G, Smith BL, Núñez G. K+ efflux is the common trigger of NLRP3 inflammasome activation by bacterial toxins and particulate matter. Immunity. 2013; 38:1142-53. https://doi. org/10.1016/j.immuni.2013.05.016 